\title{
1. A GYAKORLÓTÓL ...
}

\section{FALUS IVÁN - NAGYNÉ FÓRIS KATALIN}

A pedagógusképzésnek, mint néhány más szakmának is, lényeges eleme az elméleti és a gyakorlati képzés szintézise.

A gyakorlatok egy része az elméleti képzés befejezése után tanítani kívánt tudományterületekre, másik része a pedagógiai mesterségre készít fel. Mind a két terület igényli az elméleti ismeretek megszerzését, mind pedig a gyakorlás lehetőségeinek biztosítását. Jó esetben ezek a területek egymással összefüggésben alakulnak ki.

A gyakorlatok egy részét az elméleti tanulással párhuzamosan végzik a hallgatók, vagy a képző intézmény falai között, vagy iskolai terepen. A gyakorlat másik része iskolákban, az elméleti képzés befejezése után valósul meg. Az orvosképzéssel sok rokonvonást mutat a pedagógusok képzése. Az orvosok is átjárnak a klinikákra már az elméleti képzéssel párhuzamosan is, aztán pedig huzamosabb gyakorlaton vesznek részt.

Nagy gondot kell arra fordítani, hogy az elméletben megtanultakat megerősítse az a gyakorlat, amellyel a hallgatók szembesülnek. Ezt a tényt felismerve a hazai pedagógusképzésben már közel 150 éve létrehozták az első gyakorlóiskolát, az úgynevezett „mintaiskolát”. Egerben is több mint 80 éves múltra tekint vissza a gyakorlóiskola.

Gyakorta képezi vita tárgyát, hogy vajon szükség van-e speciális, a képzőintézményhez kötődő gyakorlóiskola fenntartására. Látszólag meggyőzőnek tűnik az az érv, hogy menjenek átlagos iskolákba a hallgatók, hiszen ilyen körülmények között kell majd tanítaniuk, jobb, ha mindjárt ezt látják, ezt tanulják meg. Ez a nézőpont figyelmen kívül hagyja a pedagógussá válás folyamatának fokozatos jellegét és azt a már korábban említett tényt, hogy a gyakorlatnak nem szabad ellentmondania a legkorszerübb elméleti ismereteknek.

A magyarországi pedagógusképzés egyik fontos vívmánya a gyakorlóiskolák megteremtése és működtetése. Ma, amikor az eredményes, hatékony pedagógus alap-, bevezető és továbbképzés egységes rendszerét kívánjuk létrehozni, támaszkodhatunk a gyakorlóiskolák több évtizedes tapasztalatára. Egyszersmind fel kell tárnunk, hogy a jelenlegi gyakorlóiskola mennyiben felel meg azoknak az elvárásoknak, amelyeket a 21. századi pedagógusképzés vele szemben támaszt. Annak az új típusú iskolának, amelyben eredményesen tanítják a tanulókat, hatékony képzési környezetet nyújtanak a tanárjelöltek számára, és amely az egyetemi oktatókkal közösen pedig igényes kutatások végzésére nyújt lehetőséget.

Az a kutatás, amelyet ebben a kötetben mutatunk be, éppen arra irányult, hogy kiderítse, hol tart ma egy tipikus gyakorlóiskola, melyek azok a legfontosabb fejlesztési feladatok, amelyeket a kívánt új minőség elérése érdekében meg kell valósítani. 
A pedagógusképző egyetemek regionális központtá válnak mind a pedagógusképzés, mind pedig a pedagógus-továbbképzés területén. Ez az új funkció indokolja, hogy a gyakorlóiskola olyan szakmai fejlesztő iskolává váljék, amely alkalmas az egyetemmel együttműködve:

- a közoktatás és a pedagógusképzés szempontjából fontos kutatások végzésére,

- az iskola alapvető funkciójának megfelelően az általános és középiskolai tanulók magas színvonalú nevelésére és oktatására,

- az iskola folyamatos önfejlesztésére,

- az iskola pedagógusai számára a folyamatos szakmai fejlődés feltételeinek megteremtésére,

- a pedagógusok felkészítésére a régión belül továbbképzési feladatok ellátására,

- regionális támogatói feladatok ellátására,

- több szempontból is modell szerep betöltésére a régió iskolái számára.

A jelen kutatás célja a szakmai fejlesztő iskolává válás folyamatát megalapozó diagnosztikus értékelés. Azaz a kutatás akkor teljesedik ki, ha folyamatos akciókutatássá válik, megtervezésre kerülnek a cél eléréséhez szükséges lépések, és folyamatos visszajelzések, korrekciók révén az iskola önfejlesztő jellege tovább formálódik, tanulóközösséggé válik. A jelenlegi helyzet feltárására alapvetően két módszert alkalmaztunk:

- az iskolai dokumentumok (pedagógiai program, versenyeredmények, pályázatok adatai) elemzését és kérdőíveket

- a tanároknak,

- tanulóknak,

- szülőknek,

- tanárjelölteknek,

- egyetemi oktatóknak,

- a beiskolázás előtt álló óvodások és a városi 8. osztályos tanulók szüleinek kiküldött kérdőívek adatainak minőségi és statisztikai módszerekkel történt mennyiségi elemzését. A kutatást egy egyetemi oktatókból, gyakorlóiskolai tanárokból és az EKE doktoranduszaiból álló kutatócsoport végezte (Dorner László EKE, Kovács Kristóf EKE, Lengyelné dr. Molnár Tünde EKE, Tóthné Parázsó Lenke EKE, Racskó Réka EKE, Göncziné Kapros Katalin EKE, Orgoványi-Gajdos Judit, EKE doktorandusz, Zagyváné Szűcs Ida, EKE doktorandusz, Kocsis Rita, EKE doktorandusz, Subrt Péter, EKE doktorandusz, Bencze Rita, EKE doktorandusz, Dobosné Földi Brigitta, EKE doktorandusz, Borsodi Csilla Noémi, EKE doktorandusz, Nagyné Fóris Katalin, tanár EKE gyakisk., Garbaczné Olasz Andrea, tanár, EKE gyakisk. Pócs Mária Magdolna, tanár, EKE gyakisk., Ringert Csaba, tanár, EKE gyakisk., doktorandusz, Szücsné Hütter Eszter, tanár, EKE gyakisk., Pap Zoltán, tanár, informatikus, EKE gyakisk.). A kutatócsoport vegyes összetétele nemcsak a kutatás eredményességéhez járult hozzá, hanem az egymástól történő tanulás számára is kiváló lehetőséget biztosított. 
Az egyes témacsoportok megválaszolásához szükséges mérőeszközöket egy-egy személy dolgozta ki, majd ezeket a kutatócsoport megbeszélésein elemeztük, korrigáltuk. Hasonló módon történt az SPSS program által vizsgálandó kérdések megfogalmazása és részben az adatok értelmezése is.

1. A kutatást az alábbi részterületeken végeztük:

2. Az iskola mint iskolaszervezet

3. Az iskola légköre

4. Az iskola színvonala, eredményessége, vonzereje

5. Az iskola külső megítélése

6. Pályázatok hatása az iskolai szereplőkre, innováció az iskolában

7. A kiemelt figyelmet igénylő tanulók méltányos fejlesztése

8. Az iskola szerepe a pedagógusjelöltek felkészítésében

9. Az iskola önfejlesztö tevékenysége

10. Az iskola és az egyetem kutatás-fejlesztésben történő együttműködése Az alábbiakban az egyes területeken kapott eredmények rövid összegzését, következtetéseket, majd az iskolafejlesztés számára megfogalmazható javaslatokat foglaljuk össze. Végezetül az egyes részterületeken túlmutató javaslatokat írjuk le.

Kutatásunk mérőeszközeinek és statisztikai adatainak elérhetősége: https://drive.google.com/drivelfolders/ $1 K F 3 N z K Z t t Q p k L Y I e U L o A O q G u m M s N E j I S ? u s p=$ sharing 